\title{
MILITARY EXPENDITURE, SPENDING CAPACITY AND BUDGET CONSTRAINT IN EIGHTEENTH-CENTURY SPAIN AND BRITAIN *
}

JOSÉ JURADO SÁNCHEZ

Complutense University of Madrid a

\begin{abstract}
Using new public spending statistics for Spain and other various indicators we show that Spain and Britain suffered larger increases in public expenditure in the periods in which they fought each other and other countries. The British Exchequer spent much more than its Spanish counterpart, especially on the Army and Navy and debt repayment. This situation helps to explain why Britain emerged victorious against Spain in the majority of these wars and was a consequence of the political and institutional changes made in England from 1688 onwards, reducing budget constraint and allowing Britain to mobilise the necessary resources to become the leading world power. In Spain, however, the changes required to eliminate the country's history of bankruptcies and increase its spending capacity were not made.
\end{abstract}

Keywords: public expenditure, military outlays, spending capacity, British and Spanish National Budgets (1 $8^{\text {th }}$ century)

JEL Classification: N13, N44

* Received 03/18/2008. Accepted 09/23/2008. The author is grateful to the Universidad Complutense of Madrid for funding part of this research (grant no PR3/04-12466). I would like to thank Javier Cuenca for providing the source used to unify the units of account of Spain and Britain, Rafael Dobado for his valuable comments, and J. P. Reeder for correcting spelling mistakes made by the author. The author, however, retains all responsibility for any remaining errors and omissions.

a Faculty of Economics and School of Business Studies, Complutense University of Madrid, Campus de Somosaguas, 28223 Pozuelo de Alarcón, Madrid, Spain (jurado@ccee.ucm.es). 


\section{RESUMEN}

Utilizando unas nuevas series del gasto de la Hacienda española y algunos otros indicadores se comprueba que España y Gran Bretaña sufrieron grandes aumentos del gasto público en aquellos periodos en que guerrearon entre sí y con otros países. El Estado británico gastó mucho más dinero que el español, sobre todo en los capítulos militares y el servicio de la Deuda, lo que contribuye a explicar por qué Gran Bretaña venció a España en la mayoría de los conflictos que libraron ambos países. Esto era, en buena parte, una consecuencia de los cambios políticos e institucionales llevados a cabo en Inglaterra a fines del siglo XVII, que limitaron las restricciones presupuestarias y facilitaron que Gran Bretaña llegara a ser la primera potencia mundial, mientras que en España no se hicieron las transformaciones necesarias para hacer olvidar su larga tradición de bancarrotas y aumentar su capacidad de gasto.

Palabras clave: gasto público, gasto militar, presupuestos, capacidad de gasto, Gran Bretaña y España (siglo XVIII)

\section{INTRODUCTION}

Military spending has generated much literature since Antiquity. As early as the fifth century B.C., Thucydides understood the relationships between expenditure and warfare and wrote that «war is a matter not so much of arms as of money, which makes arms of use» ${ }^{1}$. Several centuries later, Cicero stated in his Fifth Philippic that nervus belli, pecuniam ad infinitum ${ }^{2}$. In the early modern period, this maxim was seen as unquestionable by rulers such as Maria Theresa of Austria, statesmen like Richelieu, economists and men of letters such as Antoine de Montchrestien and writers like Rabelais $^{3}$. The same can be said for the modern period and the present, so it is hardly surprising that military spending has been the subject of considerable scholarly attention in recent decades. Military expenditure is probably the major theme in the economics of military spending and defence economics, a sub-area of economics whose origin can be traced back to World War II. Researchers in defence economics and the economics of military spending apply economic reasoning and methods to the study of issues related with defence and conflict resolution: the economic effects of military spending, arms races, the military-industrial complex, the procurement of defence equipment, the arms trade, disarmament, conversion, the peace

\footnotetext{
Thucydides (1984), p. 370

2 Cicero (1913-1921), vol. 4.

${ }^{3}$ For the statements of some of these authors see Ferguson (2001), p. 25.
} 
dividend, peace-keeping, and so on ${ }^{4}$. Nevertheless, defence economics has been, at least until the present, almost exclusively focused on the postSecond World War period. Other works on military spending during the modern period dealt with similar topics at the level of the international system and alliances before and after the First World War ${ }^{5}$.

Military outlays are also a very important topic in the extensive literature on the tax state or the fiscal-military state. The scholars of this noteworthy research field study public finance in the early modern period and its relationships with war finance, taxation, budget constraint, state building, economic growth, etc. ${ }^{6}$. It was Schumpeter (1918) who coined the term «tax state» to indicate the significant step from the medieval «domain state» to the modern form of the state. Seventy years later, John Brewer (1988) was the first scholar to use the term "fiscal-military state» to highlight that the main function of the British state in the eighteenth century was to wage and finance warfare. From then on, the fiscal-military state became a growing research field which has generated many publications ${ }^{7}$. In works on the tax state or fiscal-military states it is pointed out that warfare and the efforts made to finance it were highly influential factors in the formation of European states during the early modern period. According to Tilly (1992, p. 70), «major mobilizations for war provided the chief occasions on which states expanded, consolidated, and created new forms of political organization». Thus, a centralized and productive fiscal system began to emerge. The growing cost of armies and navies was a central reason for the growth of expenditure and hence taxation and government debt, especially from the seventeenth century onwards. It can be said, therefore, that the needs of the war fuelled the state, determining taxation and public debt and affecting the economy.

European states did not, however, have unlimited spending power and suffered budgetary constraints generated by factors such as the sources of revenue and the size and growth of their economies. Some states - such as Holland and England- made political and institutional changes in order to extend their spending capacity and so to be able to finance warfare. It seems that other states — such as France - tried frequently, but unsuccessfully, to implement financial innovations. What was the situation in Spain? Was Spain able to set up a sufficiently solid fiscal and credit system to allow the country to fight for world supremacy? To what extent could Spain rely on

4 See, for instance, Richardson (1953), Smith (1989), Intriligator (1990), Alexander (1990), Dunne (1990), Hartley and Sandler (2001).

5 See, for example, Eloranta $(2002,2007)$ and (Ferguson, 1999).

6 See, among other, the following works: Tilly (1975, 1992), Harris (1976), Webber and Widalski (1986), Parker (1988), Beckett and Turner (1990), Aerts and Crouzet (1990), Thompson (1992), Hart (1997, 2007), Bonney (1995), Hoffman and Rosenthal (1997).

7 See, for instance, Earle (1990), Ertman (1994), Bonney (1999), O’Brien and Hunt (1993), Harling and Mandler (1993), Glete (2002), Bowen and González Enciso (2006), and Torres (2007). 
capital markets to finance the spikes in expenditure required by wars? We hope, in this study, to contribute to answers these questions. The principal aim of these pages, however, is to measure and compare, accurately and systematically, the military impact and the spending capacity of Britain and Spain during the eighteenth century. This comparison would not have been possible without the new set of statistics of Spanish public expenditure recently constructed (see Appendix). Four indicators based on these new statistics and the series of Treasury spending, prices and population for Britain compiled by Mitchell and Deane (1962) were constructed. First, the contribution of military spending to the increase in total expenditure in the periods in which the Exchequers of Britain and Spain spent most was calculated. We also estimated the proportion of per capita expenditure devoted to financing the military items of the budget. This makes it possible to discover whether the Army and Navy were the items on which the Spanish and British National Treasuries spent most per head of population and whether these sums rose throughout the eighteenth century. The third indicator estimates the percentage of total expenditure dedicated to military items. We also considered GDP, another point of reference commonly used to estimate the importance of military outlays. In spite of the fact that the calculation of this macroeconomic variable for the early modern period is a hazardous exercise, several estimates of both Spanish and British GDP and GDP per head have been made ${ }^{8}$. They present very different figures which show that even though there has been much recent research leading to substantial improvements in our knowledge of GDP of both countries, estimates of this variable are closer to conjectures than definitive evidence ${ }^{9}$.

Finally, in order to compare the budgetary impact of military expenditure and the spending capacity of Great Britain and Spain accurately, the accounting units of both countries were unified using eighteenth-century rates of exchange for the pound sterling and the real of vellon. The term "purchasing power parity» (PPP) was coined in the twentieth century to identify the relationship between exchange rates and price levels, although the perception that exchange rates should be related to national price levels has been dated back to the sixteenth century. PPP states that the exchange rate between two currencies should be that which would equate the relative national prices if expressed in a common currency ${ }^{10}$. Nevertheless, the empirical evidence in favour of PPP is not very strong, and there is research reporting that this method sometimes fails to hold. Several explanations for this apparent failure have been offered. Some stem from economic considerations, i.e., the use of non tradable goods in the construction of price

8 For Britain see, for example, Crafts $(1985,1987)$ and Deane and Cole (1962). For Spain, Prados (1993), Yun (1994), Maddison (2001), van Zanden (2001 and 2005), and Carreras (2003).

9 The authors of one of the last calculations of Spanish GDP for the early modern period have stated that these estimates are «conjectural» (Álvarez-Nogal y Prados de la Escosura, 2007).

10 For a general view on the PPP method, see Sarno and Taylor (2002). 
indices and speculation regarding foreign exchange rates. Others stem from the difficulties in the empirical analysis - the use of short data series unable to capture the statistical properties of deviations from PPP, for example- - and some from policy variables, such as the varying degree of exchange rate management implied by the regimes ${ }^{11}$. In spite of these difficulties, PPP has been used fruitfully in both theoretical and empirical research on exchange rates ${ }^{12}$. Additionally, we have a reliable source at our disposal, The Course of the Exchange, a periodical which offered plentiful financial and commercial data, and for this reason has been used by numerous scholars to study many issues related to eighteenth-century finance and commerce, including those relating to the PPP method.

This article is divided into five parts. Following this theoretical and methodological introduction, in the second section we will study the budgetary impact of military spending in both Spain and Britain by estimating the contribution of Army and Navy expenditure to the increase in total spending. The third section will discuss the economic and Treasury impacts of military outlays and the budget priorities of British and Spanish rulers by calculating the weight of Army and Navy spending in several variables. In the fourth section we will debate budget constraint and examine the spending capacity of Great Britain and Spain. In the last section the main findings will be summarized highlighting the similarities and differences between Britain and Spain, and their implications for further research.

\section{THE INCREASE OF GOVERNMENT EXPENDITURE AND ITS FINANCING}

\subsection{The contribution of military spending to the increase of public expenditure}

Britain's Treasury spending increased considerably throughout the eighteenth century. In inflation-adjusted prices, its cumulative growth rate was 1.47 from 1714 onwards. The increase was greater in the second half of the century than in the first half. It was not until 1740 that total expenditure reached an average of seven million pounds sterling. In the 1760 s, it went beyond 13 million pounds, passing 17 million in the 1780 s and 24 million during the last decade of the century. In Spain, real public expenditure rose much less than in Great Britain, its cumulative growth rate being 0.46. Between 1714 and 1720 expenditure amounted to 189 million reales de vellón and more than 200 million during the next seventy years. In the 1790s, expenditure exceeded the 330 million reales de vellón mark. The

11 See, for example, Officer (1982) and Rogoff (1996).

12 For Spain in the eighteenth century, see Torres (2005). 
expenditure trends were similar in Great Britain and in Spain with particularly noteworthy increases in expenditure taking place in five periods of the century with four of these periods coinciding for both countries (see Figures 1 and 2).

The first peak in British Treasury spending took place between 1703 and 1713, when expenses doubled the totals of the previous years. A little more than 15 per cent of this increase was caused by civil budget items, especially the service of the National Debt. Military items generated most of the increase, which was due to the involvement of Britain in the War of the Spanish Succession. Army expenditure contributed almost three-fifths of the increase in total expenditure, while Navy expenditure accounted for a quarter. In Spain, the first peak in Treasury spending occurred in the period 1717-1720, when annual expenses increased 23 per cent in relation to previous years. Less than a quarter of this increase was caused by the civil items of the budget. As occurred in Britain, the majority of the rise in expenses in Spain was due to spending on military items. The cost of the Army contributed more than half of the increase, while the percentage attributable to the Navy was almost 25 per cent, as shown in Table 1. The increase during the period 1717-1720 and the others which took place in the first half of the eighteenth century (for instance, that of the period 1728-1736, when the Spanish Treasury spent, on average, 17 per cent more than in the seven preceding

FIGURE 1

GREAT BRITAIN'S TREASURY SPENDING, 1714-1800

(Annual values in million pounds sterling at constant prices)

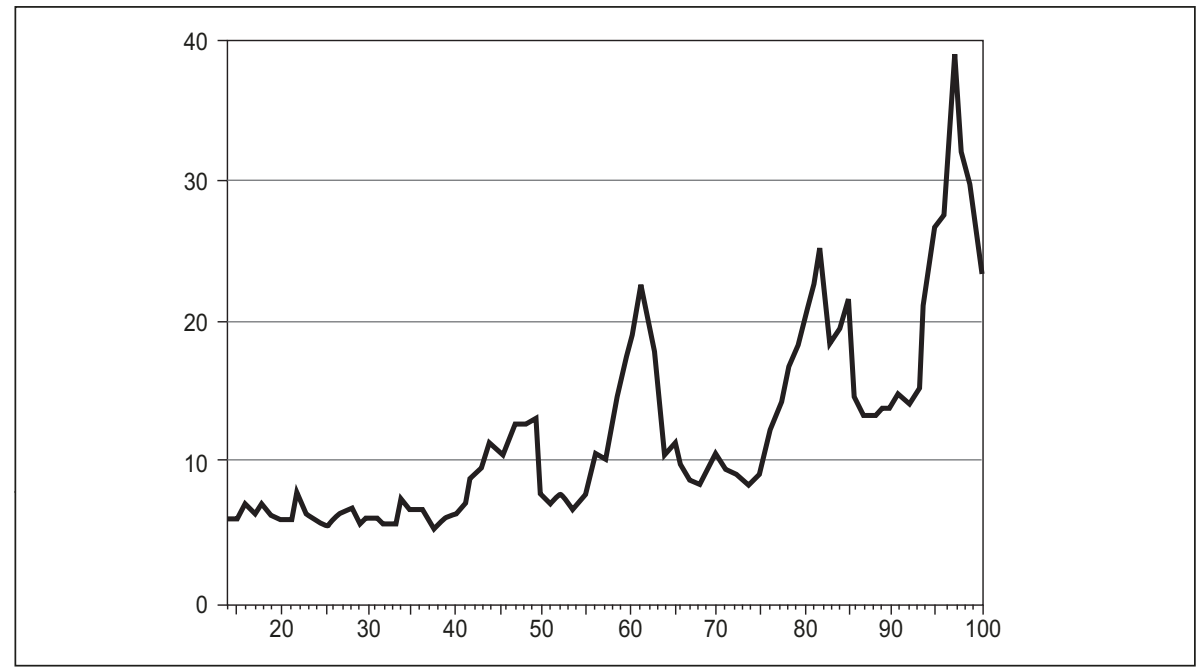

Sources: The author's own preparation based on Mitchell and Deane (1962). 
FIGURE 2

SPAIN'S TREASURY SPENDING, 1714-1800

(Annual values in million reales of vellón at constant prices)

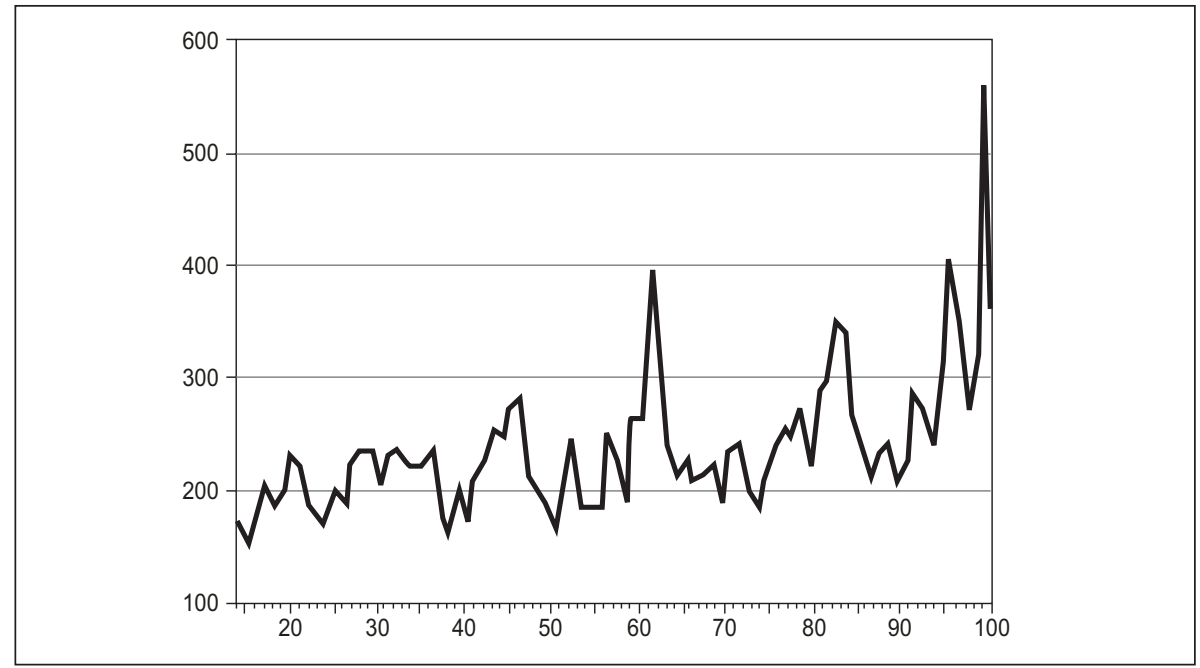

Sources: The author's own preparation based on Jurado-Sánchez (2006).

years) were caused by the wars following Philip V's refusal to accept the treaties of Utrecht. This King's foreign policy involved attempts to regain the territories lost during the War of Spanish Succession, especially those in Italy. In 1717 and 1718 Spanish troops conquered Sardinia and Sicily, but Britain, France, Austria and the Netherlands formed an alliance and ejected Spain from these territories before $1720^{13}$.

The second huge increase in Treasury spending in both Spain and Britain took place during the 1740s. In Great Britain, expenses increased by almost two-thirds between 1731-1739 and 1740-1748. This increment was caused in its entirety by the military items of the budget. Army expenditure contributed almost three-fifths of the rise in expenditure and Navy spending more than two-fifths. The service of the National Debt made up 1.5 per cent of the increase, and the rest of the civil items accounted for a negative percentage. The funding of the War of Jenkins's Ear and the War of Austrian Succession caused these increases. These wars, especially the latter, were also the most important factors behind the increase Spain's public spending between 1742 and 1746. Treasury payments during this period rose, on an average annual rate, by 40 per cent in relation to the previous five years. Civil items made up

${ }^{13}$ For the wars in which Spain participated during the reign of Philip V, see, for example, Domínguez-Ortiz (1981), pp. 49-69, and Ozanam (1996), pp. 586-93 and 625-44. 


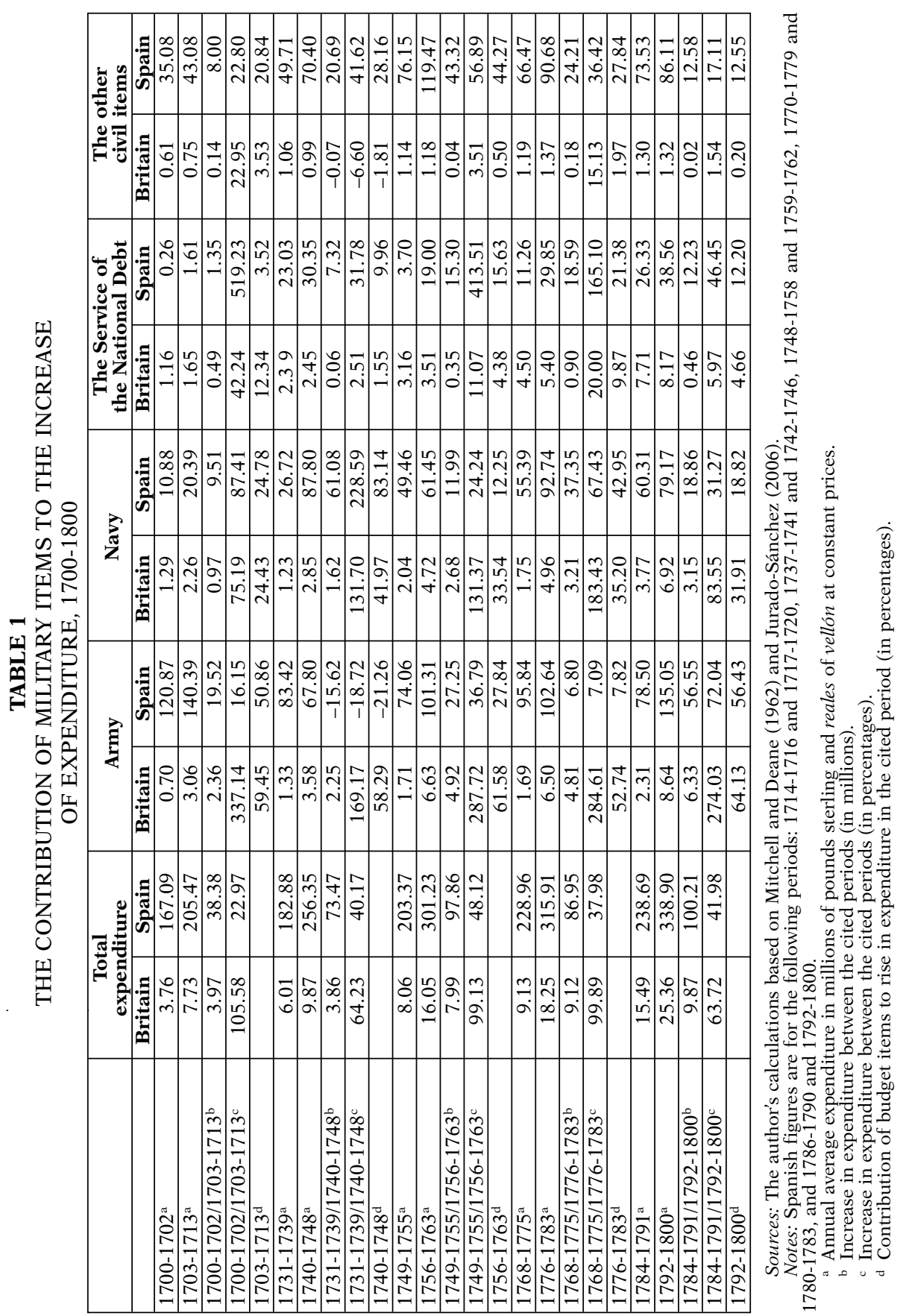


less than two-fifths of the increase, whereas more than three-fifths was due to military spending. On this occasion the Navy played the largest role in the increase, doubling its expenditure and accounting for more than four-fifths of the increase, while Army spending decreased by more than 15 per cent.

Another peak in Spanish and British Treasury spending occurred in 1756-1763 and again the increases were caused largely by a tense international situation. In Britain, the impact of military outlays on the Treasury was again greater than in Spain. After eleven years of armed peace in Europe, from 1748 onwards, military operations returned to both the Old and the New World as a result of the Seven Years War. This military conflict caused 95 per cent of the increase in public spending in Great Britain. The financing of the Army made up more than three-fifths of the increase of total expenditure, while that of the Navy contributed one-third of the total increase in expenses. Servicing the National Debt accounted for more than 4 per cent with other civil items making up the rest. Spain entered the Seven Years War in 1761, during the final stages, a circumstance that Britain used to enhance its victory. As a result of this war, the Spanish Exchequer spent 48 per cent more in 1759-1762 than in the preceding ten years. Two-fifths of this rise was due to Army and Navy expenditure and almost three-fifths to civil items. This was the only period in which the civil items of the budget played a larger part in the increase than military items, a situation which was probably due to the brief Spanish involvement in the war and to the rise in expenditure of several civil items.

Most of the increases in public expenditure which took place in Spain and Great Britain between 1776 and 1783 were also caused by the wars which broke out during this period. We refer in particular to the War of Independence of the United States of America. British Exchequer spending doubled between 1768-1775 and 1776-1783. Army spending accounted for more than half of the increase and spending on the Navy more than onethird. The cost of the service of the National Debt made up almost 10 per cent of the increase. The financing of the involvement of Spain in the War of Independence contributed considerably to pushing up expenditure in the early 1780s. Another contributing factor was the Spanish Navy's attack on Algiers to prevent Algerian raids on Spain's southern coasts. In this period, the Spanish Treasury spent almost two-fifths more than in the previous ten years. More than half of this increase was due to the Army and Navy, especially the latter, which accounted for 43 per cent of the rise because the majority of the battles in the above-mentioned wars were naval conflicts. Almost half of the increase was caused by the civil items, to a large extent due to the service of the National Debt. The notable contribution of this item was caused by the first repayments on vales reales, a hybrid of war bond and paper money issued from 1780, in part to finance the war against Britain, which increased the amount required to service the National Debt by a factor of 2.6 in the next three years. 
The last spending peak of the Spanish and British National Treasuries occurred between 1792 and 1800. The expenses of the British Exchequer grew by almost 64 per cent, almost two-thirds of this increase being generated by the financing of the Army, plus almost another third by the financing of the Navy, and almost 5 per cent by the service of the National Debt. In Spain, Treasury spending also peaked in the same period. The sum paid by the Exchequer was, on an average annual rate, 42 per cent greater than in the five-year period of 1786-1790. A little over three-quarters of this increase was due to military items of the budget. Army spending accounted for 56 per cent of the increase in expenditure as a result of the Pyrenees War, a land war in which Spain and France fought from 1793 to 1795. Navy spending made up less than one-fifth of the increase, as a result of the fact that military conflicts with Britain from 1797 onwards were largely naval. As regards civil expenses, they accounted for almost a quarter of the total increase in expenditure, half of this percentage corresponding to the service of the National Debt. It was once again the repayment of the vales reales which pushed up (up to 70 per cent) the level of this item. On average, the Exchequer paid off yearly vales to the value of 17 million reales in 1786-1794, and 83 million in 1795-1800.

If we consider the five periods in which increases in expenditure were greatest jointly, we can see that the impacts of various items of the budget on Treasury spending were different in Great Britain and in Spain. As shown in Figure 3, in Britain the impact of military spending was much gre-

FIGURE 3

THE CONTRIBUTION ON MILITARY ITEMS TO THE INCREASE OF EXPENDITURE, 1700-1800*

(In percentages of increase)

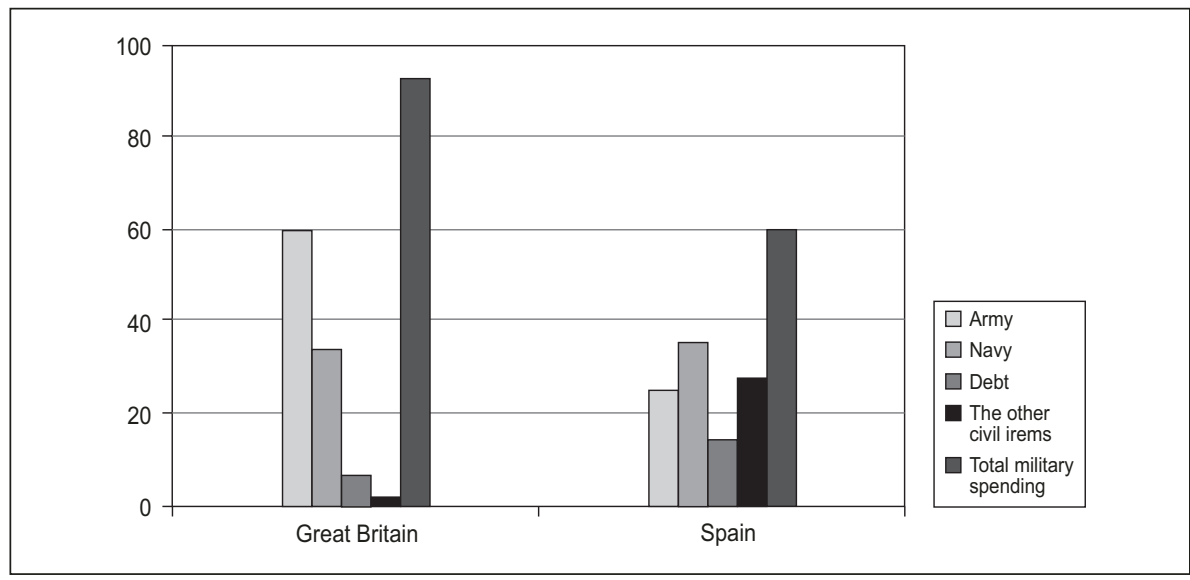

Sources: The author's computations based on Mitchell and Deane (1962) and Jurado-Sánchez (2006). Notes: * For Spain, 1714-1800. 
ater than in Spain, while in Spain the impact of civil items was greater than in Britain. In this country, almost 93 per cent of the increase in expenditure was caused by the military items of the budget, whose contribution went from 84 per cent in 1703-1713 to 100 per cent in 1740-1748 and 96 per cent in 1792-1800. Army spending made up almost three-fifths of this contribution, and spending on the Navy accounted for a little over one-third. In Spain, three-fifths of the increase was brought about by the need to finance the Army (one-quarter) and the Navy (more than one-third). This average annual percentage was even greater in 1717-1720 and 1792-1800, periods in which military outlays made up 75 per cent of increase in expenditure. As for the civil items, these accounted for two-fifths of the increase, almost 14 per cent of it being due to the service of the National Debt. In Britain, civil spending contributed to the increase in total expenditure far less than in Spain (just over 7 per cent) almost all of which was made up by debt repayment.

\subsection{The factors of financing of the increase in public spending}

Did the conflicts between Britain, Spain and other countries, in fact, raise the volume of spending permanently to a higher level? Which factors contributed to finance the increase in public expenditure? As far as the first question is concerned, Peacock and Wiseman (1961) prove that in the twentieth century public spending in the United Kingdom grew during wartime and never returned to its pre-war levels. This phenomenon, in which, firstly, expenses increased because of the financing of the wars, and later, when the conflicts finished, the increment continued due to debt servicing and other necessities caused by wars, is known as the "ratchet effect». Can the same thing be said for eighteenth-century Britain and Spain? All of the rises in British public spending are due primarily to a large increase in military outlays. Debt repayment, used to finance military needs, increased towards the end of each war and is maintained in the first years of peace. On the conclusion of a war, the increasing debt repayment line crosses the military line coming down, exceeding it by a rising margin each time ${ }^{14}$ (Figure 4). In Spain the service of the National Debt line never exceeded the military spending line (Figure 5), and total civil expenditure only exceeded military outlays in three years in the 1760s.

The large increases in public expenditure caused by the considerable financial requirements of the foreign policies of both British and Spanish rulers during the eighteenth century could only be satisfied by either large increases in tax revenue, or the issue of National Debt, or both. In Britain,

14 According to Mann (1991, pp. 485-486), this generated a permanent war state and increased public spending. 
FIGURE 4

THE «RATCHET EFFECT» IN BRITAIN'S TREASURY SPENDING, 1700-1800

(Annual values in million pounds sterling at constant prices)

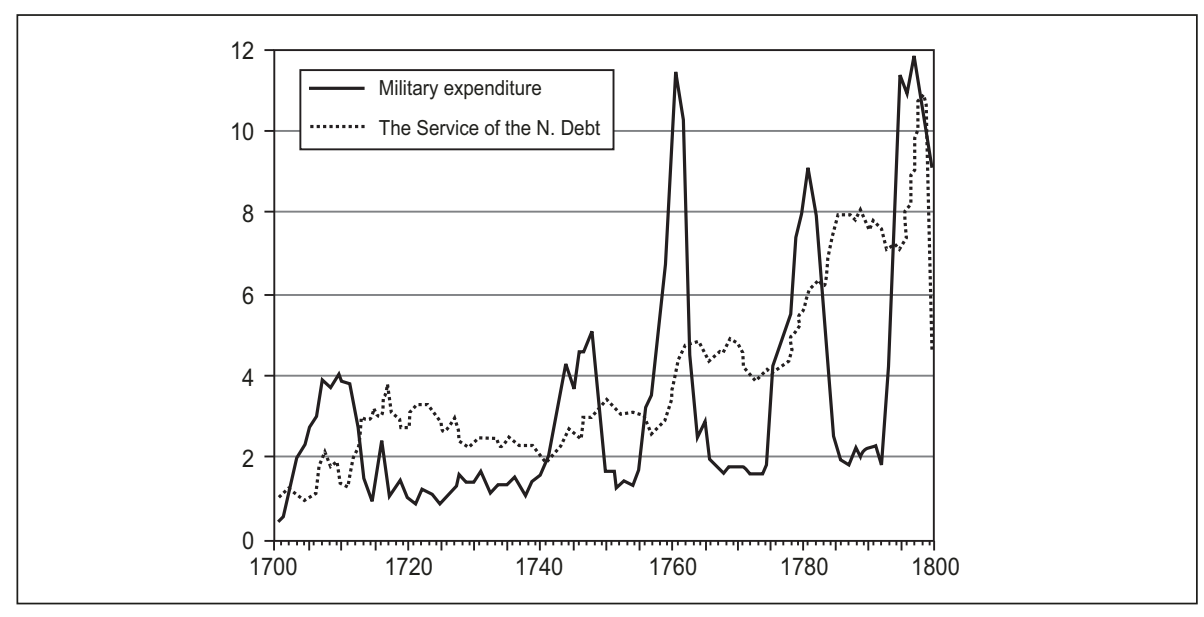

Sources: The author's own preparation based on Mitchell and Deane (1962).

FIGURE 5

THE «RATCHET EFFECT» IN SPAIN'S TREASURY SPENDING, 1714-1800

(Annual values in million reales of vellón at constant prices)

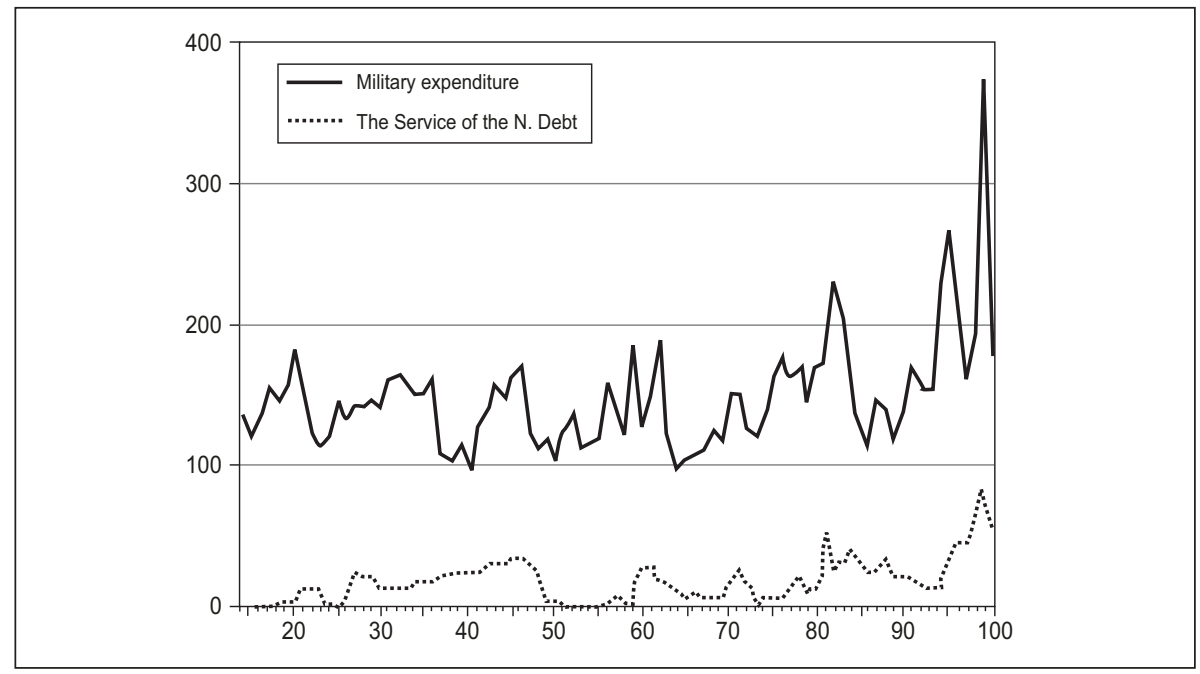

Sources: The author's own preparation based on Jurado-Sánchez (2006). 
net fiscal income grew in real terms by a factor of 3, while in Spain fiscal income rose 126 per cent between 1713 and $1742^{15}$. Several factors lay behind these increases. One factor was the positive evolution of the economies of both countries. Reconstructed estimates for the growth rates of total output suggest that Britain's real national income may have increased by a factor of around 3 during the eighteenth century ${ }^{16}$. In Spain, the crisis of the seventeenth century ended around the middle of this century, recovery beginning around 1680 . This recovery, however, was halted by the War of Spanish Succession. After the war, both population and farming output grew strongly over the following decades. Owing to the increase in demand and to the affordable prices of foodstuffs and land to rent, the output of industry and domestic and foreign trade also grew ${ }^{17}$.

Another factor which contributed to the growth of public revenue was the successful administrative management of the tax system. In Britain, this factor might have been even more important than economic growth ${ }^{18}$. In Spain, a notable part of the increase in revenue was due to the reforms which, from 1714 onwards, introduced a set of new direct taxes (the equivalentes) levied on production factors in Aragon in order to bring them into line with Castilian taxes. If economic growth and tax reforms did not yield enough money to fund the wars, British and Spanish rulers appealed for credit and, in the case of the Spanish, left a legacy of debt. The size of Britain's National Debt jumped from one million pounds sterling in 1688 to 244 million pounds in 1790 . This enormous increase was the result of a variety of institutional innovations established after the Glorious Revolution (see section 4). In Spain, the importance of the National Debt was far less than in Britain. Philip V of Spain (1701-1746) left more than 500 million reales undischarged, the so-called créditos de testamentaría ${ }^{19}$. Government debt increased considerably in the last decades of the century. The Exchequer raised 725 million reales in the first three years of the 1780 s by means of the issue of vales reales ${ }^{20}$. So, Spain was able to obtain the additional revenue with which to fund the wars of this decade, since there were no fiscal reforms and the economy stagnated from the mid 1760s. Twenty years later, Spain's economy entered a crisis, coinciding with a peak in Treasury spending as a result of the wars against France and Britain. The agrarian crisis and a sharp

15 Mitchell and Deane (1962), pp. 386-88, O’Brien (1988), pp. 1-6, García-Lombardero (1978), pp. 79-83, and Fernández-Albaladejo (1979) pp. 54-57 and 77-83.

16 Engerman and O’Brien (2004), pp. 451-57. Crafts (1985), p. 45.

17 Anes (1970), pp. 427-30. Fernández-Díaz (1985), pp. 17-53. Marcos-Martín (2000), pp. $650-70$.

18 O’Brien (1988), pp. 6-8.

19 Archivo General de Palacio, Administrativa, legajo 539.

20 Archivo General de Simancas, Dirección General del Tesoro, Inventario, 16, Guión, 23, legajo 49. 
rise in farming prices caused problems for industry as manufactured production could not continue to grow if the vast majority of the population spent its disposable income on purchasing food supplies. Trade also declined in the 1790s, since a succession of wars interrupted commerce during the next 15 years. This increase in public expenditure could only be financed by another huge issue of National vales reales of almost 1,000 million reales in the second half of the 1790s, double the figure of a few years earlier.

\section{ESTIMATING THE PROPORTION OF ARMY AND NAVY SPENDING IN SEVERAL ECONOMIC AND FISCAL VARIABLES}

Due to the difficulties involved in estimating GDP for the early modern period, it is not easy to determine the weight of military outlays in this aggregate variable accurately. Nevertheless, the available estimates of Spanish and British GDP and the calculations of Army and Navy spending for both countries presented in these pages show that the military burdens on GDP were higher in Britain than in Spain. During the second half of the eighteenth century, in Spain the financing of the Army and Navy absorbed, on average, 7 per cent of GDP, while in Britain the average percentage was almost 9 per cent. These percentages are much higher than the figures for the period 1870-1913, when the military burdens were 2 per cent of GDP in Spain and 2.6 in Britain ${ }^{21}$. The differences between the two countries are larger if military spending and debt repayment are considered jointly. The sum paid by the British Exchequer for both budgetary items accounted for more than 16 per cent of GDP and GDP per capita, double the figure spent by the Spanish Exchequer (see Table 2).

Also, in Spain, public expenditure and military spending per capita were far lower than in Britain. The growth rate of Britain's Treasury spending was far greater than that of the population. Both variables reached seven million in the 1710s, but in the last decade of the century the former increased by a factor of 3.5 to 24 million and the latter grew by less than 50 per cent to ten million. Therefore, expenditure per head of population suffered a sharp increase. The British Exchequer spent one pound sterling per head of population in the 1710s and almost two and half pounds in the 1790s (Table 3). In Spain, per capita expenditure rose by almost a quarter. The population increased, averaging out different estimates, by 42 per cent, while public spending increased by 76 per cent. In the period 1712-1717, the Spanish Exchequer spent 24 reales for each inhabitant and more than 30 in 1797.

${ }^{21}$ Eloranta (2007), p. 260. 
MILITARY EXPENDITURE, SPENDING CAPACITY AND BUDGET CONSTRAINT IN...
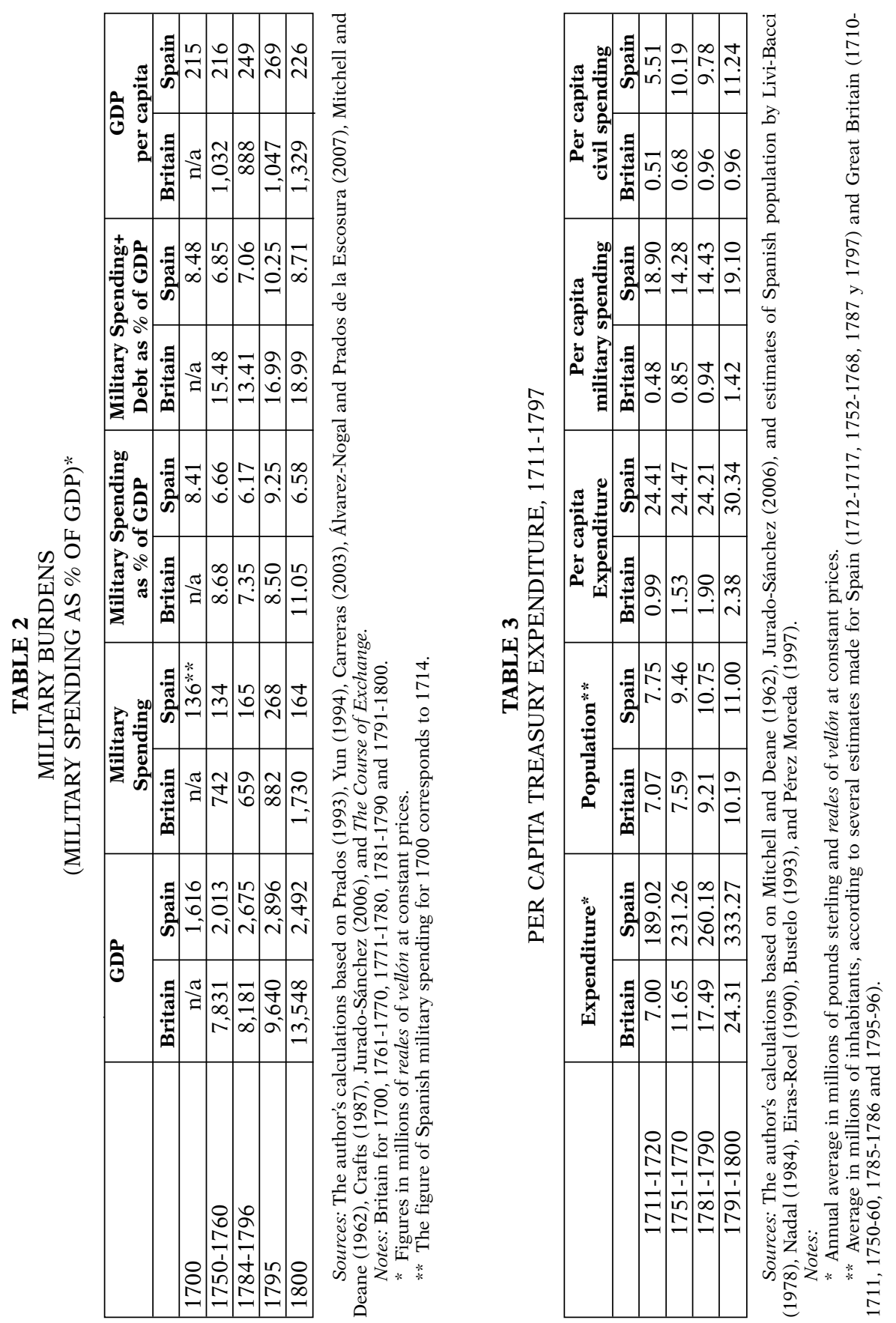
The Spanish and British Exchequers spent the majority of per capita expenditure on military items, but there were large differences between the situations in both countries. The British Army and Navy absorbed, on an annual average, 55 per cent of per capita expenditure (almost one pound sterling), and the proportion of both military items was similar: 28 per cent of expenditure per head of population was spent on the Army, while a little over a quarter was spent on the Navy. Repayment of debt was the item on which the British National Treasury spent most per head of population (more than one-third). On the contrary, the British Exchequer spent smaller amounts per capita on the other civil items (10 per cent). In Spain, the weight of military spending in per capita expenditure was far greater than in Britain, but that of servicing the National Debt was far less than that of Britain. Almost two-thirds of per capita expenditure (17 reales) were spent on the Army and Navy. In contrast with the large sums spent on military items, the Spanish Treasury spent, on average, smaller amounts per capita on civil expenses (a little over nine reales, more than one-third) (Table 3 and Figure 6).

As shown in Table 4, the structure of expenditure also shows the heavy burden that the Army and Navy represented for both the Spanish and British National Budgets during the eighteenth century. In Britain, 55 per cent of expenditure was allocated to funding the Army and Navy. This ave-

FIGURE 6

PER CAPITA EXPENDITURE, 1711-1797 *

(In percentages of total)

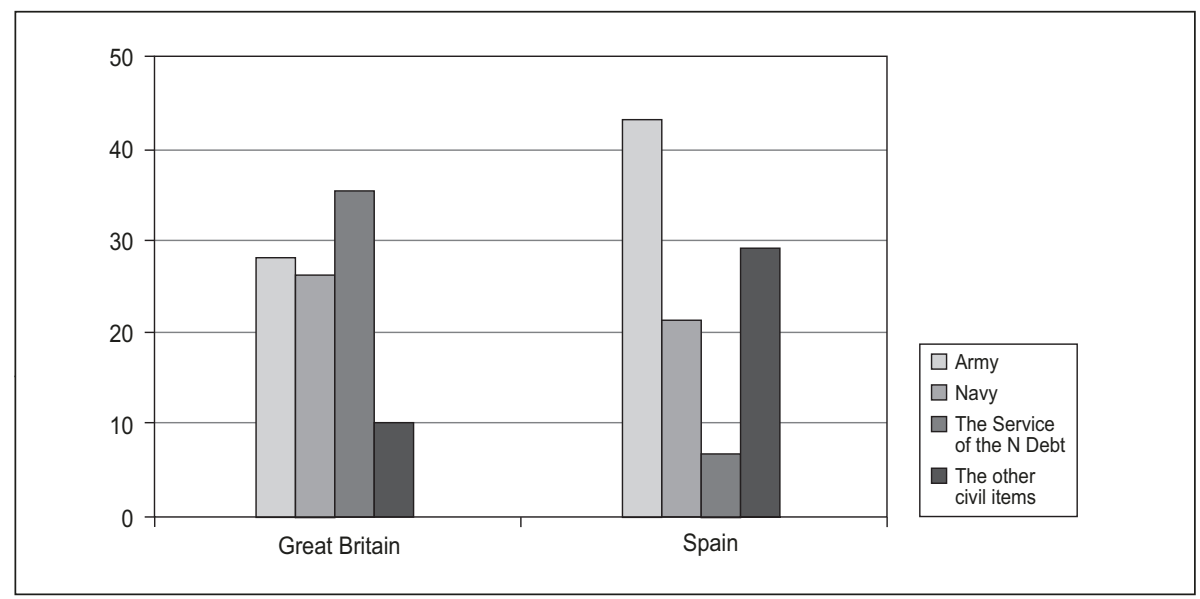

Sources: The author's computations based on references cited in Appendix and Table 3. Notes: * For Spain, 1714-1800. 
MILITARY EXPENDITURE, SPENDING CAPACITY AND BUDGET CONSTRAINT IN...

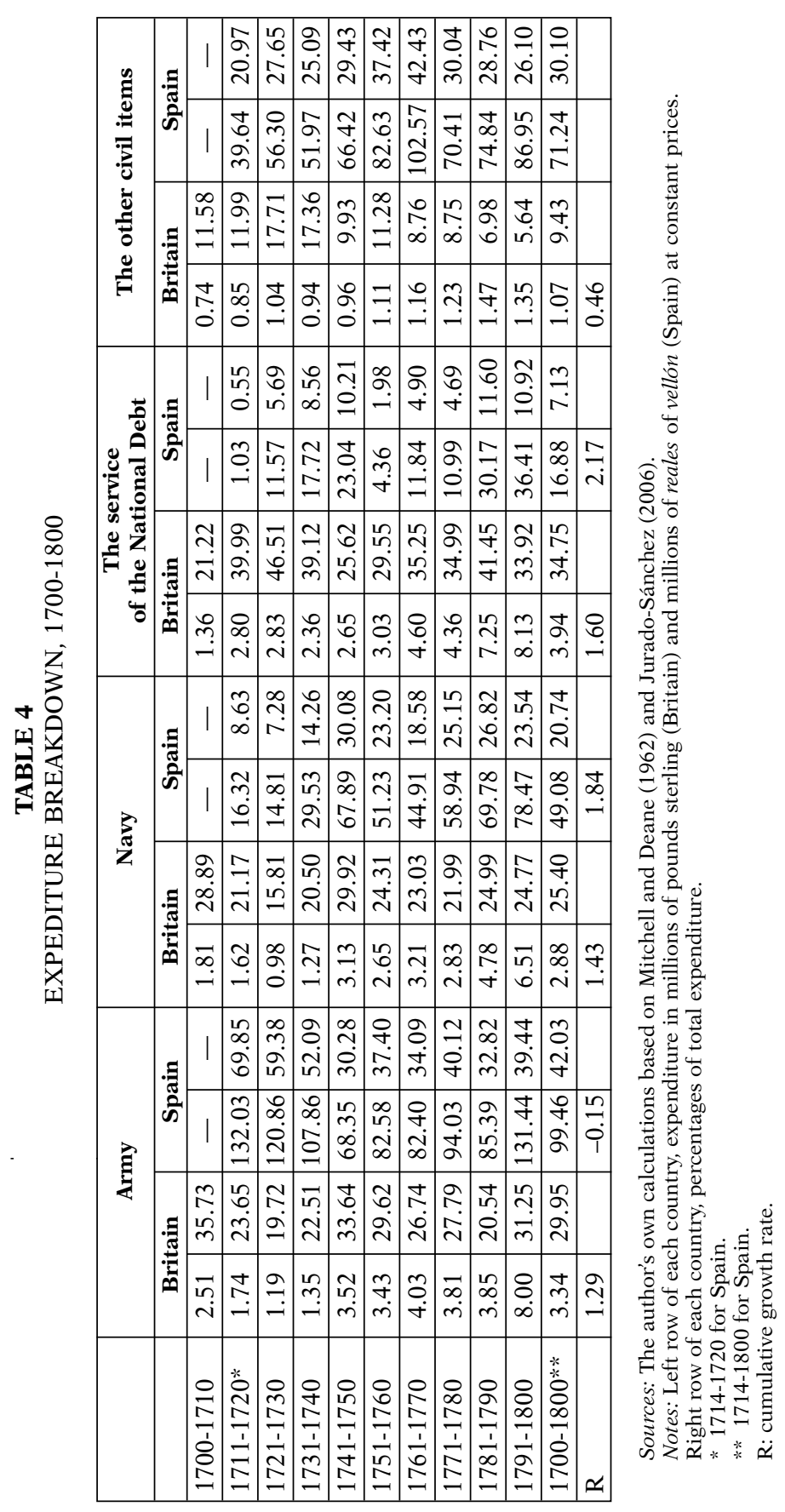


rage percentage rose considerably in the first decade of the $1700 \mathrm{~s}$, the $1740 \mathrm{~s}$ and the 1790s. The budgetary importance of the Army was greater than that of the Navy, since the former absorbed 30 per cent of total spending and the latter a quarter. The service of the National Debt was the most important item of the British budget, absorbing more than one-third of expenditure. The considerable weight of military spending in the structure of expenditure is also observable in Spain, but the importance of the service of the National Debt was a lot lower than in Great Britain, as it accounted for 7 per cent of total Spanish spending. More than three-fifths of Spain's Treasury spending was allocated to financing the Army and the Navy. This average percentage rose considerably between 1714 and 1740 and in the 1770s. The Army was the most important item of the budget, since it absorbed more than two-fifths of total expenditure and more than two-thirds of military spending. Nevertheless, the trend of the budgetary weight of the Army fell, as shown by its negative average annual rate of growth. Army spending grew significantly more in Britain than in Spain over the eighteenth century.

Unlike the Army, the Spanish Navy gained in budgetary importance over the eighteenth century. Its costs grew rapidly. The average annual amount spent on the Navy (a little over one-fifth of total expenditure) rose from the 1740s onwards, except during the 1760s. The growth of Navy spending was due to the numerous naval wars in which Spain participated and the building of large fleets for warfare. According to Ardant (1975), this was usual in eighteenth-century Europe. In Spain, two ministers, Patiño and Ensenada, encouraged increased spending on the fleet during the first half of eighteenth century in order to make Spain the major world power once again, as she had been in the sixteenth century. This policy meant that dockyards launched one hundred boats between 1717 and 1752 and Navy expenditure exceeded that of the Army by 70 per cent in 1744-1746 and by 25 per cent in 1747. The growth of the Spanish fleet continued in the following decades reaching the figure of more than two hundred ships by the end of the century ${ }^{22}$.

The Navy was more prominent in the structure of expenditure in Britain than in Spain, but spending on the Navy increased more in Spain than in Britain. This shows that the Spanish Exchequer spent more on the Navy in an attempt to reduce the advantage that its greater naval power afforded Britain. However, the strength of Spanish naval power does not appear to come any closer to Britain's, since Britain spent more (25 per cent of total expenditure) than Spain (21 per cent) and Britain had a more powerful Navy than Spain or any other European country. During the major wars of the eighteenth century, Britain had many more warships than any other world power. For instance, in the War of Austrian Succession, Britain had

22 Ozanam (1996), pp. 457-66. Merino-Navarro (1981b), p. 151. 
115 ships of the line, 82 more than the Netherlands, 70 more than France, 79 more than Spain, and 95 more than Russia. This gap narrowed in the second half of the eighteenth century, but the differences were still remarkable. In the years of the War of Independence of the United States, Britain had 30, 48 and 89 ships of the line more than France, Spain and Russia respectively, and 58, 64 y 71 more during the French Revolutionary Wars. Ships, however, are of little value if there is a shortage of crew. For this reason, Britain also massively increased the number of seaman. British naval personnel grew by a factor of almost seven between the end of the War of the Spanish Succession and the French Revolutionary Wars, when the number of sailors exceeded $92,000^{23}$.

The data on the structure of public spending may encourage economic historians to explore other interesting issues. One such issue involves the possibility of a "guns versus butter» theory in eighteenth-century Spain and Britain. This theory is the classic example of the production possibility frontier. It models the relationship between a country's investment in defence and civilian goods. A nation has to choose between two options when spending its finite resources. It can buy either guns or butter, or a combination of both. It seems that if an economy produces more guns (military expenditure) it must reduce its production of butter (civil spending) and vice versa. From the defence spending perspective, the impact and possibility of a guns vs. butter dilemma during the twentieth century has received substantial coverage in academic literature. In short, this dilemma expresses the idea that a percentage increase in social spending is accompanied by a proportional decrease in military spending and vice versa. Nevertheless, the existence of budgetary tradeoffs seems to be at best only partially supported in the empirical literature ${ }^{24}$. As far as we know, there are no studies of the existence of the guns vs. butter dilemma during the eighteenth century. Therefore, this is an issue for future economic history research to explore. It is hoped that further investigation may prove the existence of the tradeoffs between military spending and other kinds of expenses, and if so, whether they favoured Britain or Spain in the pursuit of their economic and military objectives.

\section{SPENDING CAPACITY AND BUDGET CONSTRAINT. THE GREAT ADVANTAGE OF BRITAIN}

The eighteenth century was an age of warfare as a result of the struggle for economic and political world primacy which several countries were engaged in throughout the century. Britain's ambition was to become the

23 Modelski and Thompson (1988), pp. 68-70. Kennedy (1987), pp. 99.

${ }^{24}$ See, for instance, Russet (1982), Domke, Eichenberg and Kelleher (1983), and Mintz (1989). 
leading world power. The aim of old powers like Spain and France was, at least, to maintain their status. We must also take into account the appearance of Russia on the European scene and the arrival of Prussia among the group of great military powers ${ }^{25}$. In the pursuit of their objectives, the governments of these countries tried to gather resources on a large-scale. However, the European states of the time, like households and firms, did not have unlimited spending power. Government expenditure was constrained by total receipts obtained by taxation or borrowing from the public. In turn, these sources of revenue were limited not only by the size of taxable object less the subsistence minimum, but also by the nature of the driving forces of the economy (Schumpeter, 1918). According to Collins (1988, p. 219), in seventeenth-century France there was a «fiscal limit» of some 3035 million livres for the levy of the taille, imposed by the nature of the tax and the productive wealth upon which it was levied.

To reduce budget constraints and extend their spending capacity, several states had long since introduced political and institutional changes. In the 1540s the provincial Estates of Holland started to levy efficient provincial taxes to be able to meet the financial costs of long-term public loans. In the following decade, all forced loans were abolished and a voluntary, free market for public loans emerged. Dutch public credit was maintained by an institutional web which included an efficient tax system, voluntary public loans and a mature stock market (supported by the Bank of Amsterdam). As a result, the province of Holland became an efficient entity able to mobilise funds for the wars against Spain (Hart, 2007). A comparable financial revolution occurred in England during the last years of the seventeenth century. Between the 1690s and the middle of the eighteenth century, a move away from short-term loans to regular long-term arrangements in public finance took place. A permanent national public debt was created because it established property rights and obtained the political commitment of the state, controlled by the parliament, to defray payment of the debt, sustain the institutions that underpinned it (the Bank of England) and respect for the investors who financed it. On the basis of institutional and political credibility, the British state proved highly successful in mobilising massive, cheap loans for war (Dickson, 1967). The English financial revolution generated what has been called "the square of power», consisting of a parliament (for credible tax backing of the debt), a tax bureaucracy (to collect the taxes needed to service the debt), a central bank (to maintain the market value of the debt), and the national debt (to finance wars). The effectiveness of the power emanating from this base was considerable, war being the prime mover forcing countries to adopt whatever elements of the «square of power» they could (Ferguson, 2001, pp. 15-16).

${ }^{25}$ For the international situation, see Kamen (2002), Mousnier and Labrousse (1981), pp. 32450, Domínguez-Ortiz (1981), pp. 49-64, and Kennedy (1987), pp. 73-139. 
It has been observed that the different national success stories in the eighteenth century depended on the adoption of a financial revolution like the English and the Dutch. Success, therefore, depended on the degree of flexibility that states showed in obtaining the necessary resources to wage increasingly costly wars. In the early modern period, warfare could not be financed in the traditional medieval way, i.e. by increases in taxation. Taxsmoothing was necessary, which meant borrowing during wartime and managing the debt in peacetime. In the long run, the relationship between fiscal resources and probity and a capacity for effective action in the international sphere prevailed (O'Brien and Hunt, 1999). Britain, France and Holland in the second half of the eighteenth century can be seen as examples. As a result of its long record of fiscal probity, Britain could continue to borrow a substantial fraction of its war expenditures at what were relatively low interest rates. France, on the other hand, had to depend on taxation since she had squandered her fiscal reputation from the 1770s onwards (Bordo and White, 1991). According to Ferguson (2001, p. 180), the key difference between France and Britain was a matter of institutions. Britain had a superior revenue-collecting system, a representative government, which tended to draw up transparent budgets and reduced the likelihood of default, a National Debt on which payments were generally made and was transparently managed, and a central bank which guaranteed the convertibility of the currency into gold and reduced the risk of default as a result of inflation. These institutions enabled Britain to sustain a much larger debt/GDP ratio than France because they ensured that the interest Britain paid on her debt was substantially less than what France paid on hers. In the Netherlands of the 1780s, the willingness to invest in state bonds had declined and defeat in the Anglo-Dutch war, coupled with a political crisis, weakened the revenue-raising system established in the sixteenth century (Hart, 2007).

According to North and Weingast (1989), French public finance did not undergo the transformations experienced in England and the Netherlands. French governments proved either incapable of implementing financial innovations or simply abandoned them. The same can be said for Spain where, during the sixteenth and seventeenth centuries, no financial revolution along English or Dutch lines took place. Tax and administrative reforms of the eighteenth century either achieved efficient institutional change, which could lead to limited and more costly access to national and international credit markets, seriously restricting Spain's spending capacity and hence eroding her possibilities of defeating Britain. In addition, it seems that eighteenth-century Spanish statesmen lived with the worry about how to pay back debt and the desire not to generate any more. This public-debt aversion prevented any reasonable debt market from being set up (González Enciso, 2007). Also, it has been argued that Spain was a poor country whose weak economy never possessed enough human and material 
resources to maintain its Empire, and that if she managed to do so during the sixteenth and seventeenth centuries it was due to the fact that Spain was able to gather and channel men, money, technology, weapons and warships from other peoples and territories. However, in the eighteenth century changes in the international situation prevented the access of Spain to foreign resources ${ }^{26}$. Given that in this century, in spite of economic growth, the presumption is that Spain's resources remained inadequate to maintain her empire, we believe, then, that it would have been very difficult for Spain to contend world primacy with Britain. We consider that, besides these factors, the Spanish state had a long history of defaults which could have restricted its access to credit markets. The Spanish Exchequer declared the crown insolvent or suspended payments on several occasions during the early modern period $(1557,1598,1607,1647,1652,1662,1739 \ldots)$. Default and the premium paid on a history of default were to become critical features in the later stages. The Spanish state could not fail to make payments on a frequent basis without a ruinous loss to its reputation at home and abroad, and therefore weakening her ability to borrow in the future. It would appear that, in the eighteenth century, Spain was unable to pass the real test which consisted of mobilising sufficient resources for war and, hence, to become the leading world power. This test involved the capacity of government to borrow and the interaction between the constraints on borrowing and the power to tax.

It seems that all these facts generated a budgetary inadequacy in Spain which prevented the country from gaining world supremacy. The comparative figures between Britain and Spain serve to corroborate the budgetary inferiority of the Spanish Exchequer with respect to its British counterpart. If we unify the accounting units of both countries and use only the Spanish currency (the real of vellón), the large differences between Great Britain and Spain, not only in terms of the impact of military expenditure on treasury spending, but also in the spending capacity of both countries, become clear. On an average annual rate, the British Exchequer spent five times more than its Spanish counterpart in the 87 years following the War of the Spanish Succession. This difference became even greater in the last two decades of the century, when public spending in reales was almost eight times higher in Great Britain than in Spain. The expenditure of the Spanish state reached its highest level in the 1730s (37 per cent of that of the British) and the lowest in the 1780 s and the 1790 s (13 per cent), precisely the decades when Britain gained the upper hand in its rivalry with France and Spain to achieve world supremacy. The same conclusion is reached if the volume and trend of military spending and the service of the National Debt in both countries are compared. As regards the former, the Exchequer of Britain

${ }^{26}$ (Kamen, 2002). For the financial and economic foundations of the Spanish Empire, see also Bernal (2005). 
spent more than four and half times the sum spent by its Spanish counterpart, with the largest differences being recorded in the second half of the eighteenth century, during the period in which both countries fought several wars. The Spanish Exchequer reached the highest percentage in the twenty-five year period following the War of the Spanish Succession, a period in which it spent three-fifths of Great Britain's military expenditure on the Army and Navy. Spain fell further behind from the 1740s onwards, especially during the decades in which Spain and Britain were at war, and again the lowest level was reached in the 1790s. We can obtain a better idea of Britain's budgetary supremacy by comparing figures concerning the service of the National Debt of both countries. On average, in Spain this item did not even reach 4 per cent of the British figure with the highest percentage being recorded in the 1740s (almost 8.5 per cent) (Table 5).

The per capita expenditure in reales and the contribution of military outlays to the increase in expenditure also show the great advantage that Britain enjoyed in spending capacity in comparison with Spain. In 17141800 , the contribution of the Spanish population to total expenditure and military spending was, on average, 26 and 19 reales respectively. These figures were less than 15 and 19 per cent of the contribution of the British population, percentages which were to fall, especially in the last decade of the century, when they were about 11 per cent (Table 6). However, the difference between the efforts made by the British and Spanish to finance wars was not as great as shown by these percentages. The 97 reales paid, on average, by each Briton represented 9 per cent of per capita income, while the 19 reales paid by each Spaniard were almost 7 per cent of GDP per head. This was due to the fact that real Spanish GDP and real GDP per capita were about half and one-quarter respectively of those of Britain (Table 2).

Great Britain's budgetary superiority during the great wars in which Britain and Spain fought during the eighteenth century is clear. The British Exchequer's spending increased between six and fourteen times more than that of Spain (six times during the War of Jenkins's Ear and the War of the Austrian Succession and fourteen times during the French Revolutionary Wars). British superiority on the battlefield was even greater than these figures show, since 90 per cent of the increase in public spending was due to the financing of the Army and Navy, while in Spain this percentage was about two-thirds. Spanish spending on the Army and Navy was between 10 and 20 times less than Britain's during the aforementioned wars, reaching the latter percentage during the Seven Years War and the former during the War of Austrian Succession (Table 7) ${ }^{27}$. These figures not only help to explain why Great Britain emerged victorious against Spain in the majority of the wars of the eighteenth century, but they also reflect the heavy burden

27 Torres Sánchez (2007), pp. 442-4, reached similar conclusions when he analysed the spending capacity of Spain and Britain on the occasion of the American War of Independence. 


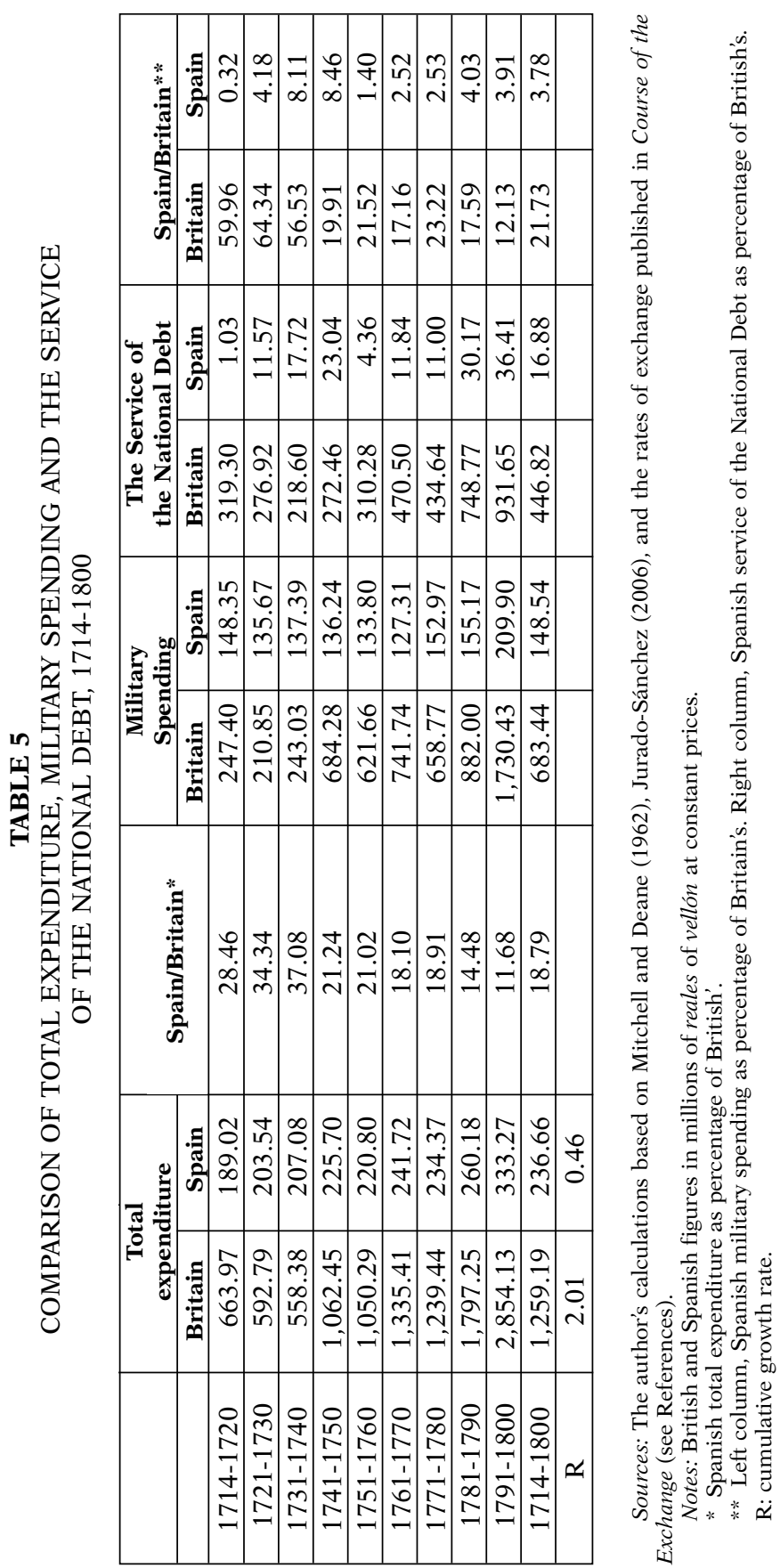


that the numerous conflicts represented not only on the Spanish and British National Treasuries and GDP, but also in many other European countries ${ }^{28}$.

TABLE 6

COMPARISON OF PER CAPITA TREASURY EXPENDITURE, 1714-1800

\begin{tabular}{|l|r|c|c|r|r|r|r|r|}
\hline & \multicolumn{2}{|c|}{$\begin{array}{c}\text { Total } \\
\text { expenditure }\end{array}$} & \multicolumn{2}{|c|}{ Population** $^{\text {Total per capita }}$} & \multicolumn{2}{c|}{$\begin{array}{c}\text { Per capita Military } \\
\text { expediture } \\
\text { Spending*** }\end{array}$} \\
\hline & \multicolumn{1}{|c|}{ Britain } & \multicolumn{1}{|c|}{ Spain } & Britain & Spain & Britain & Spain & Britain & Spain \\
\hline $1714-1720$ & 663.97 & 189.02 & 7.07 & 7.75 & 93.91 & 24.41 & 34.99 & 19.14 \\
\hline $1751-1770$ & $1,192.85$ & 231.26 & 7.59 & 9.46 & 157.16 & 24.47 & 89.81 & 13.80 \\
\hline $1781-1790$ & $1,797.25$ & 260.18 & 9.21 & 10.75 & 195.14 & 24.21 & 95.76 & 14.43 \\
\hline $1791-1800$ & $2,854.13$ & 333.27 & 10.19 & 11.00 & 280.19 & 30.34 & 169.82 & 19.09 \\
\hline $1714-1800$ & & & & & 181.60 & 25.86 & 97.6 & 16.62 \\
\hline
\end{tabular}

Sources: The author's computations based on Mitchell and Deane (1962), Jurado-Sánchez (2006), Livi-Bacci (1978), Nadal (1984), Eiras-Roel (1990), Bustelo (1993), and Pérez Moreda (1997).

Notes:

* Annual average in millions of reales of vellón at constant prices.

** Average in millions of inhabitants, according to several estimates made for Spain and Britain (see Table 3).

*** Average in reales of vellón.

\section{CONCLUSIONS}

Public spending trends and the factors involved in its financing were similar in Great Britain and Spain during the eighteenth century. Both countries suffered large increases in expenditure in the periods in which they fought each other and other countries. Therefore, rivalry between Spain and Britain was a highly influential key factor in the volume and structure of public expenditure in both countries. The spending capacity of Britain was far greater than that of Spain: the British Exchequer spent five times more than its Spanish counterpart and the growth rate of total expenditure was three times greater in Britain than in Spain. Furthermore, in Spain the level of expenditure per head of population was only 14 per cent of the British figure. The level of Spain's military spending was a little over one-fifth of Britain's and that of the National Debt was less than 4 per cent of Britain's. The effort made by the British economy and population to finance war was greater than those made by Spain. The financing of the Army and Navy absorbed 9 per cent of British GDP and per capita income (more than 16 per cent if the service of the National Debt is included). In

28 See, for instance, Körner (1995). 


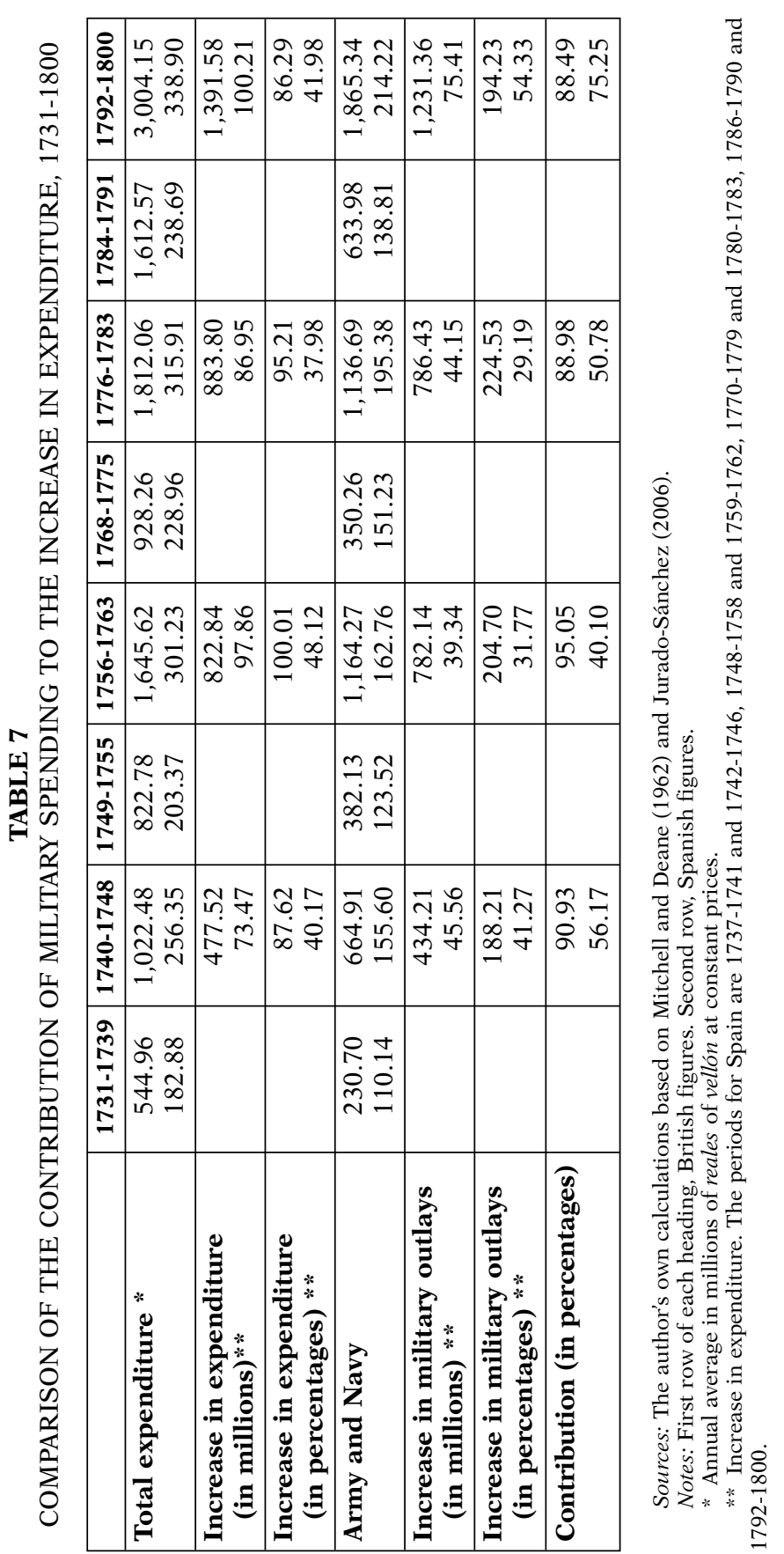


Spain, these percentages were almost 7 and 8 per cent respectively. These differences explain why Great Britain defeated Spain in the majority of these wars and are probably the result of the English financial revolution which took place at the end of the seventeenth century. Britain was able to mobilise the necessary resources to become the leading world power, while Spanish governments did not introduce enough political and institutional changes to eliminate the country's history of defaults and increase its spending capacity. This article opens the door for further significant studies in economic history, two of them being the examination of the economic effects of public spending and the exploration of the existence of the guns vs. butter tradeoffs in the Spanish and British National Treasuries during the eighteenth century.

\section{REFERENCES}

Aerts, E., and Crouzet, F. (eds.) (1990): «Economic Effects of the French Revolutionary and Napoleonic Wars». Proceedings of the Tenth International Economic History Conference, Leuven.

Alexander, W. R. J. (1990): «The Impact of Defence Spending on Economic Growth: A Multisectorial Approach to Defence Spending and Economic Growth with Evidence from Developed Economies». Defence Economics, 2 (1), pp. 39-55.

Álvarez-Nogal, C., and Prados DE la Escosura, L. (2007): "The decline of Spain (15001800): conjectural estimates». European Review of Economic History, II, pp. 319 366.

ANES, G. (1970): Las crisis agrarias en la España moderna, Madrid: Taurus Ediciones.

ARDANT, G. (1975): «Financial Policy and Economic Infrastructure of Modern States and Nations", in Ch. Tilly, The Formation of National States in Western Europe, Princeton: Princeton University Press, pp. 164-242.

BARBIER, J., y KLEIN, H. S. (1985): «Las prioridades de un monarca ilustrado: el gasto público bajo el reinado de Carlos III». Revista de Historia Económica, 3, pp. 473495.

Beckett, J., and Turner, M. (1990): «Taxation and Economic Growth in EighteenthCentury England». Economic History Review, 43, 3, pp. 373-403.

Bernal, A. M. (2005): España, proyecto inacabado. Los costes/beneficios del Imperio, Madrid: Marcial Pons.

Bonney, R. (ed.) (1995): Economic System and State Finance, Oxford: Clarendom Press.

- (ed.) (1999): The Rise of the Fiscal State in Europe, c.1200-1815, Oxford: Oxford University Press.

Bordo, M., and White, E. N. (1991): «A Tale of Two Currencies: British and French Finance during the Napoleonic War». Journal of Economic History, 51, pp. 303-316.

Bowen, H. V., and GonzÁLEz-Enciso, A. (eds.) (2006): Mobilising Resources for War: Britain and Spain at Work during the Early Modern Period, Pamplona: EUNSA.

Brewer, J. (1989): The Sinews of Power. War, Money and the English State, 1688-1783, London: Unwin Hyman.

Bustelo, F. (1993): "La población: del estancamiento a la recuperación», in P. Molas, La transición del siglo XVII al XVIII. Entre la decadencia y la recuperación, Historia de España Menéndez Pidal, vol. 28. Madrid: Espasa-Calpe, pp. 509-549. 
CARreras, A. (2003): «Spain», en J. MoKyr (ed.), The Oxford Encyclopedia of Economic History, vol. 4, Oxford: Oxford University Press, pp. 539-553.

Cicero, M. T. (1913-1921): The Orations of Marcus Tullius Cicero, London: Bell and Sons.

Collins, J. B. (1988): Fiscal Limits of Absolutism: Direct Taxation in Early SeventeenthCentury France, Berkeley.

CRAFTS, N. F. R. (1985): British economic growth during the Industrial Revolution, Oxford: Clarendom Press.

- (1987): «British Economic Growth, 1700-1850; Some Difficulties of Interpretation». Explorations in Economic History, 24, pp. 245-268.

Course of the Exchange (The), bi-weekly issues published by John Castaign and Edward Wetenhall (microfilm series to 1816 and original since 1817 in the Goldsmith Library, Senate House, University of London).

Deane, P., and Cole, W. A. (1962): British Economic Growth, 1688-1959, Cambridge: Cambridge University Press.

Dickson, P. G. M. (1967): The Financial Revolution in England: A Study in the Development of Public Credit, 1688-1756, London: Macmillan.

Domínguez-Ortiz A. (1981): Sociedad y Estado en el siglo XVIII español, Barcelona, Ariel.

Domke, W. K.; Eichenberg, R. C., and Kelleher, C. M. (1983): «The Illusion of Choice: Defense and Welfare in Advanced Industrial Democracies, 1948-1978». American Political Science Review, 77, pp. 19-35.

DunNe, P. (1990): «The Political Economy of Military Expenditure: an introduction». Cambridge Journal of Economics, 14, 4, pp. 395-404.

Earle, P. (1990): «The Sinews of Power: War, Money and the English State, 16881783». Economic History Review, 43, pp. 1-42.

Ertman, T. (1994): «The Sinews of Power and European State-Building theory», in L. STONE, An Imperial State at War: Britain from 1688 to 1815, London: Routledge.

EIRAS-RoEl, A. (1990): Estudios sobre agricultura y población en la España moderna, Santiago de Compostela: Tórculo.

ELORANTA, J. (2002): «European states in the international arms trade, 1920-1937: the impact of external threats, market forces, and domestic constraints». Scandinavian Economic History Review, 50, pp. 44-67.

- (2007): «From the great illusion to the Great War: Military spending behaviour of the Great Powers, 1870-1913». European Review of Economic History, II, pp. 255-283.

Engerman, S. L., and O'BRIEN, P. K. (2004): «The industrial revolution in global perspective», in R. Floud and P. JoHnson (eds.), The Cambridge Economic History of Modern Britain. Industrialisation (vol. 1), 1700-1860, Cambridge: Cambridge University Press, pp. 451-464.

Ferguson, N. (1999): The Pity of War: Explaining World War I, New York: Basic Books.

- (2001): The Cash Nexus. Money and Power in the Modern World, 1700-2000, New York: Basic Books.

FernándeZ-Albaladejo, P. (1979): «El decreto de suspensión de pagos de 1739: análisis e implicaciones». Moneda y Crédito, 142, pp. 51-85.

FERnándeZ-Díaz, R. (ed.) (1985): España en el siglo XVIII. Homenaje a Pierre Vilar, Barcelona: Crítica.

GARCíA-LOMBARDERO, J. (1978): "Algunos problemas de la administración y cobranzas de las rentas provinciales en la primera mitad del siglo XVIII», in A. OTAZU (ed.), Dinero y crédito (siglos XVI al XIX). Actas I Congreso Internacional de Historia Económica, Madrid: Moneda y Crédito, pp. 63-87. 
GLETE, J. (2002): War and the State in Early Modern Europe: Spain, the Dutch Republic and Sweden as fiscal-military States, 1500-1650, London: Routledge.

GonZÁlez Enciso, A. (2007): «A Moderate and Rational Absolutism. Spanish Fiscal Policy in the First Half of the Eighteenth Century», in Torres (ed.), War, State and Development. Fiscal-Military States in the Eighteenth Century, Pamplona: EUNSA, pp. 109-132.

Harling, P., and Mandler, P. (1993): «From "fiscal-military” state to laissez faire state 1760-1850». Journal of British Studies, 32, no 1, pp. 44-70.

HARRIS, R. D. (1976): «French Finances and the American War, 1777-1783». Journal of Modern History, 48, pp. 233-258.

Hart, M. (1993): The Making of a Bourgeois State: War, Politics, and Finance in the Dutch Revolt, Manchester: Manchester University Press.

- (2007): «Mobilising resources for war. The Dutch and British Financial Revolutions compared», in ToRRES (ed.), War, State and Development. Fiscal-Military States in the Eighteenth Century, Pamplona: EUNSA, pp. 179-200.

Hartley, K., and SANDler, T. (eds.) (2001): The Economics of Defence, Cheltenham and Northampton: Edward Elgar Publishing.

Hoffman, P. T., and Rosenthal, J. L. (1997): «The political economy of warfare and taxation in early modern Europe: historical lessons for economic development», in J. N. Drobak and J. V. C. Nye (eds.), The Frontiers of the New Institutional Economics, San Diego: The Academic Press.

INTRILIGator, M. D. (1990): «On the Nature and Scope of Defence Economics». Defence Economics, 1 (1), pp. 3-11.

JuRAdo-SÁnchez, J. (2006): El gasto de la Hacienda española durante el siglo XVIII. Cuantía y estructura de los pagos del Estado (1703-1800), Madrid: Instituto de Estudios Fiscales.

KamEN, H. (1969): The War of Succession in Spain, 1700-1715, Bloomington: Indiana University Press.

- (2002): Spain's Road to Empire, Allen Lane: Penguin Press.

KENNEDY, P. (1987): The rise and fall of the great powers: economic change and military conflict from 1500 to 2000, New York: Random House.

KöRnER, M. (1995): «Expenditure», in R. BonNey (ed.), Economic System and State Finance, Oxford: Clarendom Press, pp. 393-422.

Livi-BaccI, M. (1978): «La fecundidad y el crecimiento demográfico en España en los siglos XVIII y XIX», in D. V. Glass y R. ReVElle (eds.), Población y cambio social. Estudios de demografía histórica, Madrid; Tecnos, pp. 176-187.

Maddison, A. (2001): The World Economy. A Millennial Perspective, París: OECD.

Mann, M. (1986): The Sources of Social Power. A history of power from the beginning to A.D. 1760, Cambridge: Cambridge University Press.

Marcos-Martín, A. (2000): España en los siglos XVI, XVII y XVIII. Economía y sociedad, Barcelona: Crítica.

Merino-Navarro, J. P. (1981a): «La Hacienda de Carlos IV». Hacienda Pública Española, 69, pp. 139-81.

- (1981b): La Armada española en el siglo XVIII, Madrid: Fundación Universitaria Española.

- (1987): Las cuentas de la Administración central española, 1750-1820, Madrid: Instituto de Estudios Fiscales.

Mintz, A. (1989): «"Guns vs. Butter": A Disaggregated Analysis». American Political Science Review, 83, pp. 1285-1293.

Mitchell, B. R., and DeAne, P. (1962): Abstract of British Historical Statistics, London: Cambridge University Press. 
Modelski, G., and Thompson, W. R. (1988): Seapower in Global Policitics, 1494-1993, London: MacMillan Press.

Mousnier, R., and Labrousse, E. (1981): El siglo XVIII. Revolución intelectual, técnica $y$ politica (1715-1815), Barcelona: Ediciones Destino.

NADAL, J. (1984): La población española (siglos XVI-XX), Barcelona: Ariel.

North, D. C., and WeIngast, B. (1989): «Constitutions and Commitment: the Evolution of Institutions Government Public Choice in Seventeenth-Century Britain». The Journal of Economic History, 49, 4, pp. 803-832.

O'BRIEN, P. K. (1988): «The political economy of British taxation, 1660-1815». Economic History Review, 1, pp. 1-32.

O'Brien, P. K., and Hunt, P. A. (1993): "The Rise of a Fiscal State in England, $1485-$ 1815». Historical Research. The Bulletin of the Institute of Historical Research, 66, pp. 129-176.

- (1999): «England, 1485-1815», in R. Bonney (ed.), The Rise of the Fiscal State in Europe, c.1200-1815, Oxford: Oxford University Press.

OFFICER, L. H. (1982): Purchasing power parity and exchange rates: theory, evidence and relevance, Greenwich: JAI Press.

OzANAM, D. (1978): "Notas para un estudio de los presupuestos de la monarquía española a mediados del siglo XVIII", in A. OTAZU (ed.), Dinero y crédito (siglos XVI-XIX). Actas I Coloquio Internacional de Historia Económica, Madrid: Moneda y Crédito, pp. 49-62.

- (1996): "La política exterior de España en tiempo de Felipe V y Fernando VI», in J. M. Jover-Zamora (dir.), La época de los primeros Borbones. I. La nueva monarquía y su posición en Europa (1700-1759). Historia de España Menéndez Pidal, Madrid: Espasa-Calpe, vol. 29. pp. 441-699.

PARKER, G. (1988): The Military Revolution: Military Innovation and the Rise of the West, 1500-1800, Cambridge: Cambridge University Press.

Peacock, A. T., and Wiseman, J. (1961): The Growth of Public Expenditure in the United Kingdom, Princeton: Princeton University Press.

PÉrez-Moreda, V. (1997): «La evolución demográfica», in L. DE RosA and L. M. ENCISORecio (eds.), Spagna e Mezzogiorno d'Italia nell'Etá della Transizione (1650-1750), Napoli: Edicione Scientifiche Italiana, pp. 139-144.

Pieper, R. (1988): Die spanischen Kronfinanzen in der zweiten Hälfte des 18. Jahrhunderts (1753-1788): ökonomische und soziale Auswirkungen, Stuttgar: Franz Steiner.

Prados, L. (1993): "La pérdida del imperio y sus consecuencias económicas», en L. Prados y S. AmARAL (eds.), La independencia americana: sus consecuencias económicas, Madrid: Alianza, pp. 253-300.

Richardson, L. F. (1953): "The Submissiveness of Nations». British Journal of Statistical Psychology, VI (II), pp. 77-90.

Rogoff, K. (1996): «The Purchasing Power Parity Puzzle». Journal of Economic Literature, 34, pp. 647-668.

Russet, B. (1982): «Defense expenditures and National Well Being». American Political Science Review, 76, pp. 767-777.

SARnO, L., and TAYlOR, M. P. (2002): The economics of exchange rates, Cambridge: Cambridge University Press.

Schumpeter, J. A. (1918): «Die Krise des Steuerstaates». Zeifragen aus dem Gebiet des Soziologie, 4, pp. 1-71.

Sмітн (1989): «Models of Military Expenditure». Journal of Applied Econometrics, 4 (4), pp. $345-359$. 
Thompson, I. A. A. (1992): «Taxation, military spending and the domestic economy in Castile in the later sixteenth century», in I. A. A. Thompson (ed.), War and Society in Habsburg Spain. Selected Essays, Aldershot: Variorum, pp. 1-21.

Tilly, Ch. (1975): The Formation of National States in Western Europe, Princeton: Princeton University Press.

- (1992): Coercion, Capital, and European States, A.D. 990-1990, Oxford.

Torres SÁnchez, R., Gómez Bizcarri, J., and Pérez de Gracia, F. (2005): «Exchange Rate Behavior and Excange Rate Puzzles: why the $18^{\text {th }}$ Century might help». Revista de Historia Económica, 1, pp. 143-174.

- (ed.) (2007): War, State and Development. Fiscal-Military States in the Eighteenth Century, Pamplona: EUNSA.

- (2007): «Possibilities and Limits: Testing the Fiscal-Military State in the AngloSpanish War of 1779-1783", in Torres (ed.), War, State and Development. FiscalMilitary States in the Eighteenth Century, Pamplona: EUNSA, pp. 437-460.

Thucydides (1984): The History of the Peloponnesian War, Chicago: Encyclopaedia Britannica.

Weber, C., and Widalsky, A. (1986): A History of Taxation and Expenditure in the Western World, New York.

YUN, B. (1994): «Proposals to Quantify Long Term Performance in the Kingdom of Castile, 1550-1800", en A. MADDISON y H. VAN DER WEE (coords.), Economic growth and structural change. Comparative approaches over the long run on the basis of reconstructed national accounts, Proceedings of the B13 session, XI International Economic History Congress, Milán.

ZANDEN, J. L. VAN (2001): «Early modern economic growth: a survey of the European economy, 1500-1800», en M. PRAK (ed.), Early Modern Capitalism, Londres: Routledge, pp. 69-87.

- (2005): «Una estimación del crecimiento económico en la Edad Moderna». Investigaciones de Historia Económica, 2, pp. 9-38.

\section{APPENDIX}

There is no doubt that if primary source material is consulted during research into economic history, it is crucial to carry out source criticism to check its reliability and suitability for the investigation in question. There are four types of archival sources containing data to estimate the volume and structure of Spanish government spending during the eighteenth century:

1. Reports on the situation of the National Treasury made by the senior officials of the Exchequer.

2. Financial summaries, statements and estimates issued by several fiscal bodies.

3. The accounts of the Tesorería General and the Tesoreria Mayor, the central treasuries of the Exchequer which managed and centralised revenue and expenses.

4. The accounts of the Tesoreria General and the Tesoreria Mayor supervised by the Contaduria Mayor de Cuentas, the auditing body of the 
State Treasury which was under the obligation to give the accounts the final approval.

Sources 3 and 4 present great advantages over the others for estimating annual public outlays. Firstly, they contain reliable yearly data pertaining to the whole of the eighteenth century which were generated by the same fiscal body for the same aim, i.e. to present public accounts. The other sources only contain data for some periods of this century and were generated by diverse institutions for various purposes. Secondly, sources 3 and 4 contain records of actual expenditures, while the other sources contain estimates of spending. Finally, source 4 presents a valuable additional advantage in relation to source 3: the revisions by the Contaduría were final and settled the accounts. Sources 1 to 4 have been used by a number of scholars to estimate Spanish public expenditure. The most plausible of the estimates were made between 1969 and 2006, when several Treasury scholars published seven series of statistics. Henry Kamen (1969) constructed a series for the years 1703-18 using, at least in part, source 4. Didier Ozanam (1978) made another estimate by consulting source 2 , in this case for nine years of the period 1723-60. José P. Merino $(1981,1987)$ constructed two series, one of them for the years 1788-97 and another for the 1753-1820 period. He used, in the second case, the accounts of the central Treasuries, source 3. The same archival source was consulted by Jacques Barbier and Herbert S. Klein (1985) to estimate the volume of public expenditure for the 1760-1788 period. Renate Pieper used source 4 constructing the sixth series for the period from 1753 to 1780 . This source has also been used by José JuradoSánchez (2006) to compile several statistics of volume and structure of public spending, but his estimate covers the 1714-1800 era, that is to say the whole century except the first thirteen years.

In our view, until the work of José Jurado-Sánchez was published there were no acceptable statistics which would allow us to know with a degree of certainty the volume and the structure of Spain's Treasury spending and its fluctuations, the aims and role of Spanish Public Finance and to analyse its economic effects. It had also been impossible to carry out international comparisons for the whole of the eighteenth century like those made in this work. Considered jointly, the six estimates made between 1969 and 1988 leave much to be desired. Their authors did not calculate figures for thirty years of the first half of the century and statistics made for the second half present very different results. If 1760 is taken as an example, we can see that for this year four estimates have been made and all of them present large differences. The figure calculated by Merino (1987) is three times greater than that of Ozanam and one and half times more than that presented by Barbier and Klein and Pieper. The same can be said as for other years (see Jurado-Sánchez, 2006, Tables II.2 and II.3, pp. 31-33). These enormous differences are due to several factors: difficulties in the use of archive mate- 
rials, the diverse primary sources upon which estimates are based, inadequate data processing and the fact that five sets of data have been constructed at current prices and only one (that of Barbier and Klein) at constant prices. Therefore, the abovementioned six series are very different estimates which cover various periods of the eighteenth century, are not comparable and it is very difficult to integrate them into a single homogeneous series. There is no doubt that the estimates made by Jurado-Sánchez markedly improve the statistics of Spanish public spending at our disposal. There are several powerful reasons for choosing his statistics in order to achieve the aims of this work. Firstly, it is the only series which covers practically the whole eighteenth century. The other estimates cover only a part of the century, that of Merino (1987), which is the longest, includes data for 48 years. In the second place, Jurado-Sánchez used the optimal archive source: the accounts of central treasurers of the Exchequer audited by the Contaduría Mayor de Cuentas. It is true that Kamen, at least in part, and Pieper also used this source, but only to estimate public spending for 16 and 28 years of the century respectively. In addition, the Jurado-Sánchez series not only covers the whole of the eighteenth century and is based on the best archival source, but it has also been compiled with adequate data processing and has been deflated with the optimal index prices. Barbier and Klein also constructed their series at constant prices and with adequate data processing, but their estimate only covers 29 years of the century. In the following Table the statistics used in this article are presented, i.e. the public spending series constructed by Jurado-Sánchez for Spain and Mitchell and Deane for Britain. 
JOSÉ JURADO SÁNCHEZ

\begin{tabular}{|c|c|c|c|c|c|}
\hline Year & Britain & Spain & Year & Britain & Spain \\
\hline 1714 & 6,005 & 172,933 & 1758 & 12,453 & 188,303 \\
\hline 1715 & 5,988 & 155,149 & 1759 & 15,382 & 261,574 \\
\hline 1716 & 7,147 & 173,195 & 1760 & 18,360 & 263,241 \\
\hline 1717 & 6,195 & 203,042 & 1761 & 22,460 & 392,394 \\
\hline 1718 & 6,832 & 186,896 & 1762 & 21,319 & 287,711 \\
\hline 1719 & 6,342 & 200,697 & 1763 & 17,723 & 234,265 \\
\hline 1720 & 5,884 & 231,263 & 1764 & 10,476 & 210,437 \\
\hline 1721 & 5,873 & 221,735 & 1765 & 11,337 & 225,626 \\
\hline 1722 & 7,585 & 187,019 & 1766 & 9,639 & 207,876 \\
\hline 1723 & 6,372 & 170,606 & 1767 & 8,842 & 212,174 \\
\hline 1724 & 5,785 & 170,602 & 1768 & 8,469 & 222,946 \\
\hline 1725 & 5,687 & 200,796 & 1769 & 9,666 & 189,104 \\
\hline 1726 & 5,434 & 189,791 & 1770 & 10,524 & 234,670 \\
\hline 1727 & 6,104 & 219,709 & 1771 & 9,445 & 236,671 \\
\hline 1728 & 6,570 & 234,171 & 1772 & 9,167 & 200,373 \\
\hline 1729 & 5,491 & 236,457 & 1773 & 8,384 & 184,002 \\
\hline 1730 & 5,867 & 204,490 & 1774 & 8,247 & 207,342 \\
\hline 1731 & 6,076 & 229,658 & 1775 & 9,173 & 233,246 \\
\hline 1732 & 5,589 & 233,768 & 1776 & 12,320 & 254,621 \\
\hline 1733 & 5,406 & 226,345 & 1777 & 14,129 & 249,013 \\
\hline 1734 & 7,227 & 220,157 & 1778 & 15,333 & 269,771 \\
\hline 1735 & 6,575 & 219,857 & 1779 & 17,760 & 219,925 \\
\hline 1736 & 6,659 & 234,972 & 1780 & 20,550 & 288,736 \\
\hline 1737 & 5,515 & 176,470 & 1781 & 22,443 & 291,326 \\
\hline 1738 & 5,192 & 163,649 & 1782 & 25,202 & 346,623 \\
\hline 1739 & 5,854 & 196,426 & 1783 & 18,225 & 336,962 \\
\hline 1740 & 6,161 & 169,510 & 1784 & 19,242 & 267.070 \\
\hline 1741 & 6,841 & 208,372 & 1785 & 21,527 & 239,050 \\
\hline 1742 & 8,619 & 227,304 & 1786 & 14,267 & 213,372 \\
\hline 1743 & 9,552 & 254,599 & 1787 & 13,234 & 235,308 \\
\hline 1744 & 11,188 & 247,217 & 1788 & 13,502 & 240,273 \\
\hline 1745 & 10,494 & 270,925 & 1789 & 13,691 & 207,903 \\
\hline 1746 & 10,542 & 281,687 & 1790 & 13,547 & 223,940 \\
\hline 1747 & 12,726 & 212,992 & 1791 & 14,873 & 282,603 \\
\hline 1748 & 12,705 & 194,992 & 1792 & 13,896 & 269,201 \\
\hline 1749 & 13,067 & 190,679 & 1793 & 15,212 & 237,067 \\
\hline 1750 & 7,563 & 168,245 & 1794 & 21,107 & 315,126 \\
\hline 1751 & 7,139 & 221,741 & 1795 & 26,528 & 399,251 \\
\hline 1752 & 7,567 & 243,837 & 1796 & 27,514 & 351,393 \\
\hline 1753 & 6,613 & 185,805 & 1797 & 38,952 & 271,974 \\
\hline 1754 & 6,700 & 187,060 & 1798 & 32,042 & 320,316 \\
\hline 1755 & 7,738 & 183,206 & 1799 & 29,637 & 555,772 \\
\hline 1756 & 10,423 & 248,347 & 1800 & 23,364 & 329,989 \\
\hline 1757 & 10,288 & 224,920 & & R: 1.47 & R: 0.46 \\
\hline
\end{tabular}

Sources: The author's own preparation based on the data series of Mitchell and Deane (1962) and Jurado-Sánchez (2006).

Notes: British figures in 000 pound sterling at constant prices. Spanish figures in 000 reales of vellón at constant prices. R: Cumulative growth rate. 